\title{
COVID-19 salgınının ileri yaştaki kişilerde psikolojik etkileri
}

\author{
The psychological impacts of COVID-19 outbreak among older adults
}

\author{
Bengü Yücens, Ahmet Büber
}

Gönderilme tarihi:24.12.2021

Kabul tarihi:03.02.2022

Öz

Amaç: COVID-19 salgınının ve karantina süreçlerinin önemli psikososyal sonuçları olmuştur. Bu çalışmanın amacı ileri yaştaki kişilerde salgın sürecinin anksiyete ve depresyon belirtileri üzerine etkilerinin ve bu belirtiler ile ilişkili faktörlerin ortaya konmasıdır.

Gereç ve yöntem: Online anket yöntemiyle ulaşılan 65 yaş ve üstünde olan 306 kişi çalışmaya dahil edilmiştir. Katılımcılara birinci derece yakınında sağlık çalışanının olup olmadığı, COVID-19 hastalığını geçirip geçirmediği, salgın sonrasında fiziksel aktivitesinde azalma olup olmadığı gibi COVID-19 ile ilişkili soruları da içeren sosyodemografik veri formu ve Hastane Anksiyete Depresyon Ölçeği (HADÖ) uygulanmıştır.

Bulgular: Katılımcıların (167'si kadın, \%54,6) yaş ortalaması 69,46 $\pm 4,69$ 'du. Katılımcıların 29'u (\%9,5) COVID-19 geçirdiğini, 247'si $(\% 80,7)$ salgın sonrasında fiziksel aktivitesinde azalma olduğunu bildirmiştir. Depresyon ve anksiyete alt ölçeklerinden eşik üstü puan alanların sıklıkları sırasıyla \%28,8 ve \%28,4 olarak saptanmıştır. Eşik üstü depresyon semptomu sıklığı birinci derece yakınlarında sağlık çalışanı olanlarda daha az, fiziksel aktivitesinde azalma olanlarda daha sık; eşik üstü anksiyete semptomu sıklığı ise kadınlarda, kırsal alanlarda yaşayanlarda ve eğitim düzeyi düşük olanlarda daha sık olarak saptanmıştır. Lojistik regresyon analizlerinde salgından sonra fiziksel aktivite azalması eşik üstü depresif semptom varlığını; kırsal alanda yaşamak ve daha kısa süre eğitim almış olmak eşik üstü anksiyete semptomu varlığını öngörmüştür. Ayrıca birinci derece yakınlarında sağlık çalışanı olması da depresyon semptomu riski açısından koruyucu bulunmuştur.

Sonuç: İleri yaştaki kişilerde COVID-19 salgınının olumsuz psikolojik sonuçları olmuştur. Bu sonuçları engelleyebilmek için önlem alınırken kırsal alanda yaşayan, eğitim düzeyi düşük ileri yaşta kişiler öncelikle hedeflenmeli ve fiziksel aktivitelerini artırıcı yöntemler kullanılmalıdır. Bu sonuçlar ileri yaştaki kişilerde ortaya çıkabilecek psikiyatrik bozuklukların önlenmesinde ve tedavisinde yol gösterici olabilir.

Anahtar kelimeler: Anksiyete, depresyon, pandemik, yaşlı.

Yücens B, Büber A. COVID-19 salgınının ileri yaştaki kişilerde psikolojik etkileri. Pam Tıp Derg 2022;15:345354.

\begin{abstract}
Purpose: The COVID-19 outbreak and the quarantine period had important psychosocial consequences. This study aimed to reveal the effects of the outbreak on anxiety and depression symptoms in older people and the factors associated with these symptoms.

Materials and methods: Three hundred six people over the age of 65 were included in this study. Sociodemographic data form containing questions related to COVID-19 such as whether there is a health worker in their first-degree relatives, whether they have had COVID-19, whether there is a decrease in the frequency of physical activity and Hospital Anxiety Depression Scale (HADS) were applied in the online survey. Results: The mean age of the participants was $69.46 \pm 4.69$ (167 women, 54.6\%). Twenty-nine (9.5\%) of the participants reported that they had COVID-19, and 247 (80.7\%) reported that their physical activity decreased after the outbreak. The frequencies of those with above-threshold scores in depression and anxiety subscales were $28.8 \%$ and $28.4 \%$, respectively. The frequency of above-threshold depression sypmtoms was less in those whose first-degree relatives are healthcare worker and more frequently in those with a decrease in daily physical activity. The frequency of above-threshold anxiety symptoms was more common in women, those living in rural areas, and those with low education. In the logistic regression analysis the decrease in physical activity after the epidemic predicted the presence of above-threshold depression symptoms; living in a rural area and having a shorter education level predicted the presence of above-threshold anxiety symptoms. In addition, having a first-degree relative of a healthcare worker was also found to be protective in terms of depression symptom risk. Conclusion: The COVID-19 outbreak had negative psychological consequences on older adults. While taking precautions to prevent these results, older people living in rural areas with low education should be targeted first, and physical activity should be increased. Knowing these results can guide the prevention and treatment of psychiatric disorders that may occur in older people.
\end{abstract}

Key words: Anxiety, depression, elderly, pandemic.

Yucens B, Buber A. The psychological impacts of COVID-19 pandemic among older adults. Pam Med J 2022;15:345-354.

Bengü Yücens, Doç. Dr. Pamukkale Üniversitesi, Tıp Fakültesi, Psikiyatri Anabilim Dalı, Denizli, Türkiye, e-posta: dr.bengubaz@yahoo.com (https://orcid.org/0000-0002-4721-7288) (Sorumlu Yazar)

Ahmet Büber, Dr. Öğr. Üye. Pamukkale Üniversitesi, Tıp Fakültesi, Çocuk ve Ergen Psikiyatrisi Anabilim Dalı, Denizli, Türkiye, e-posta: ahmetbuber@gmail.com (https://orcid.org/0000-0001-6293-2565) 


\section{Giriş}

Çin'in Wuhan kentinde başlayan ve 2019 yılının mart ayında ülkemizde de ortaya çıkan Koronavirüs-19 hastalığı (COVID-19) milyonlarca insanın sağlığını tehdit etmiştir. COVID-19'un dünya genelinde salgın haline gelmesiyle birlikte hastalığın yayılmasını azaltmak için birçok önlem alınmıştır. Vaka sayılarındaki artışla birlikte ileri yaştaki kişilerin genç yaştaki yetişkinlere göre hastalıktan daha çok etkilendiği, mortalite oranlarının daha yüksek olduğu görülmüştür [1]. Çin ve Amerika Birleşik Devletleri'nde COVID-19 kaynaklı ölümlerin $\% 80$ 'inden fazlasını 60 yaş üstü kişiler oluşturmuştur [2, 3]. Bu nedenlerle dünya genelinde yüksek riskli kişileri koruyabilmek, mortaliteyi azaltmak, yükü hızlı bir şekilde artan sağlık sistemlerinin işleyişini sürdürebilmek amacıyla özellikle ileri yaşta olan kişilerin mümkün olduğunca daha çok evde kalması önerilmiştir.

Ülkemizde de karantina süreçleri yüksek riskleri nedeniyle 65 yaş üstü kişiler için genç yetişkinlere göre daha uzun süreli olarak düzenlenmiştir. Hafta içi günde sadece 3-4 saat süreyle sokağa çıkma, hafta sonu boyunca sokağa çıkmama, bazen 1-2 hafta sürekli sokağa çıkmama şeklinde karantina uygulamaları olmuştur. Uzun karantina süreçleri insanların özgürlüklerinin kısıtlanmasına, akrabalarıyla ve arkadaşlarıyla görüşememelerine, yalnızlık hissetmelerine neden olabilmektedir. Sosyal katılımın ileri yaştaki kişilerin sağlığı için koruyucu etkilerinin olduğu, fiziksel aktivite düzeyini ve bilişsel işlevleri artırıcı bir uyarıcı olarak görüldüğü çeşitli araştırmalarda bildirilmektedir [4, 5]. Ülkemizde çocuklarıyla, torunlarıyla birlikte sık vakit geçiren hatta birlikte yaşayan ileri yaştaki kişilerin birçoğu salgın boyunca hastalık riskini azaltabilmek için sosyal izolasyona maruz kalmıştır. Sosyal izolasyon psikolojik durumu olumsuz etkilemektedir ve depresyon, anksiyete riskini artırmaktadır [6]. Anksiyete ve depresyon belirtileri de yaşam kalitesinde düşme, fiziksel sağlıkta bozulma ve mortalite artışı ile ilişkili olduğundan ileri yaştaki kişilerde bu belirtilerin saptanması ve tedavilerinin sağlanması önem taşımaktadır $[7,8]$. Illeri yaşta kişilerde depresyon tanısı sıklıkla gözden kaçabilmekte ve tedavisiz kalabilmektedir [9]. COVID-19 salgını sürecinde hastalık bulaşma riski ve uzayan karantina süreçleri nedeniyle ileri yaşta kişilerin hastaneye başvuruları da kısıtlanmıştır. Bu kısıtııık tanı alamama ve tedavisiz kalma intimalini daha da artırabilecek bir durumdur.

Salgınlar sırasında hastalığın bulaşmasını azaltabilmek için karantina etkili ve gerekli bir yöntem olabilir ancak bu yöntem uygulanırken özellikli bazı grupların ruhsal sağlıklarının korunabilmesi için önlemler alınması uygun olacaktır. Bu önlemlerin belirlenebilmesi için de COVID-19 salgınının psikolojik etkilerinin gösterilmesine intiyaç vardır. $\mathrm{Bu}$ alanda ülkemizde çok sayıda çalışma yapılmış olsa da salgın sürecinde mortalite riski yüksek olan ve sosyal alanda kısıtılıklara daha çok maruz kalan ileri yaştaki kişiler üzerinde görece az çalışma yapılmıştır. Bu çalışmada da COVID-19 salgınının ileri yaştaki kişilerin anksiyete ve depresyon belirtileri üzerine etkilerinin açığa çıkarılması ve bu belirtiler ile ilişkili faktörlerin belirlenmesi amaçlanmıştır. Bu çalışmanın hipotezleri ileri yaştaki kişilerden birinci derece sağlık çalışanı yakını olanlarda, fiziksel aktivitesinde azalma olanlarda, eğitim düzeyi düşük olanlarda, kendisi veya yakını COVID-19 geçirmiş olanlarda eşik üstü anksiyete ve depresyon belirtilerinin daha yüksek olabileceğidir.

\section{Gereç ve yöntem}

Çalışmaya başlamadan önce T.C. Sağlık Bakanlığı COVID-19 Konusunda Bilimsel Araştırma Platformundan ve Pamukkale Üniversitesi Girişimsel Olmayan Klinik Araştırmalar Etik Kurulu'ndan izin alınmıştır.

Çalışmaya alınacak kişi sayısı için örneklem hesaplaması evreni bilinmeyen örneklem formülü ile yapılmıştır. Anksiyete ve depresyon belirtilerinin eşik üstü değerde görülme sıklığı çalışmanın yapılacağı grupta \%10 olarak kabul edilmiştir [10]. Kişi sayısının belirlenmesi için sapma payı $d=0,03$ olacak şekilde hesaplama yapıldığında, 384 kişinin çalışmaya dahil edilmesi gerektiği hesaplanmıştır. Çalışmaya 541 kişi katılmıştır. Katılımcılardan 156 tanesi 65 yaşın altında olduğu için, 79 kişi de anketi tam olarak doldurmadığı için çalışma dışında bırakılmış, böylece nihai olarak 306 kişi araştırmaya dahil edilmiştir.

COVID-19 hastalığı yakın temas ile bulaşabildiğinden, 65 yaş ve üstündeki örneklem grubuna ulaşabilmek için araştırma 
internet ortamı üzerinden yapılmıştır. Online anket oluşturulmuş ve anket linkleri mesajlaşma programları üstünden paylaşılmıştır. Anketin ilk sayfasında araştırma ile ilgili detaylı bilgi verilmiş, araştırmaya katılmayı kabul edenler anket formunu doldurmuştur. Sosyal medya veya internet kullanamayan katılımcılarda akrabaları yüz yüze görüşme ile katılımcıların anketini doldurmuştur. Çalışmaya dahil edilme kriterleri 65 yaş ve üzerinde olmak, okur yazar olmak ve çalışmaya katılmayı kabul etmek olarak belirlenmiştir. Çalışmadan dışlanma kriterleri ise anketleri doldurmaya engel olabilecek nörobilişsel bozukluk (demans, deliryum) veya mental retardasyonun bulunması ve anketlerin eksik doldurulması olarak belirlenmiştir. Araştırma salgın başlangıcından yaklaşık bir yıl sonra Şubat 2021-Nisan 2021 tarihleri arasında yapılmıştır.

\section{Veri toplama araçlari}

\section{Sosyodemografik veri formu}

Tarafımızca hazırlanan bu ankette katılımcıların cinsiyet, yaş, medeni durum, nerede yaşadığı, kiminle yaşadığı, eğitim durumu, gelir düzeyi, kronik bir hastalığının olup olmadığı, psikiyatrik bozukluk tanısının olup olmadığı gibi sosyodemografik verilerle ilgili sorular yer almaktadır. Bunun yanı sıra birinci derece yakınlarında sağlık çalışanının olup olmadığı, COVID-19 geçirip geçirmediği, birinci derece yakınında COVID-19 geçiren birinin olup olmadığı, fiziksel aktivitesinde azalma olup olmadığı, yakın akrabaları ile görüşme sıklığında azalma olup olmadığı gibi COVID-19 ile ilişkili sorular da yer almaktadır. Anket toplamda 23 sorudan oluşmaktadır ve yaklaşık 5-10 dakika sürmektedir.

\section{Hastane Anksiyete ve Depresyon Ölçeği (HADÖ)}

Hastane Anksiyete ve Depresyon Ölçeği (HADÖ), Zigmond ve Snaith tarafından geliştirilmiştir. Ölçeğin amacı tanı koymak değildir, hastaların psikolojik durumlarını ölçmek ve gerekli önlemleri alabilmektir. Anksiyete ile ilişkili 7 sorudan oluşan anksiyete ölçeğinden ve depresyon ile ilişkili 7 sorudan oluşan depresyon ölçeğinden oluşmaktadır. Her soruda, dört farklı seçenek vardır ve bu seçenekler 0-3 puan olarak puanlanır. HADÖ anksiyete ve depresyon alt ölçekleri için en iyi sonucun 11 veya üzeri bir puan olduğu bulunduğundan [11] bu çalışmada da depresyon ve anksiyete alt ölçekleri için kesme puanı 11 olarak kabul edilmiştir. Ölçeğin Türkçe versiyonunun geçerlilik ve güvenilirliği Aydemir ve ark. [12] tarafından yapılmıştır ve çalışmamızda ölçeğin Cronbach's alfa değeri 0,86 olarak saptanmıştır. Çalışmamızda bu ölçeğin kullanılmasının sebebi, tıbbi hastalıkların sık görüldüğü ileri yaştaki kişilerden oluşan örneklemimizde depresyon ve anksiyete belirtilerinin taranmasını sağlayacağının ve çevrimiçi uygulanmasının kolay olacağının öngörülmesidir.

\section{İstatistiksel değerlendirme}

Veriler SPSS Statistics 25.0 paket programı ile analiz edilmiştir. Sürekli

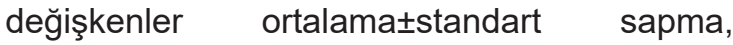
kategorik değişkenler sayı ve yüzde olarak verilmiştir. Kolmogorov Smirnov testi ile sürekli değişkenlerin normal dağılım gösterdiği saptanmıştır. Sosyodemografik özellikler, COVID-19 ilişkili bilgiler ile HADÖ puanları açısından gruplar arasında karşılaştırma kategorik değişkenler için Ki-kare analizi ile; sürekli değişkenler için normal dağılım sağlandığından Student $\mathrm{t}$ test ile yapılmıştır. Sürekli değişkenler arasındaki korelasyon analizinde normal dağılım sağlandığından Pearson korelasyon testi kullanılmıştır. Depresyon ve anksiyete semptomlarının öngörücü faktörlerinin belirlenebilmesi için lojistik regresyon analizi kullanılmıştır. Bu analizlerde depresyon/anksiyete semptomu eşik üstü olan ve olmayan gruplar arasında farklılık gösteren değişkenler bağımsız değişken olarak alınmıştır. Depresif belirtilerin varlığını öngören faktörlerin belirlenmesi için yapılan lojistik regresyon analizinde depresyon bağımlı değişken; birinci derece sağlık çalışanı yakını olması ve salgından sonra fiziksel aktivite azalması bağımsız değişkenler olarak alınmıştır. Anksiyete belirtilerinin varlığını öngören faktörlerin belirlenmesi için yapılan lojistik regresyon analizinde ise anksiyete bağımlı değişken; cinsiyet, yaşadığı yer ve eğitim durumu bağımsız değişkenler olarak alınmıştır.

\section{Bulgular}

Çalışmaya dahil edilen kişi sayısı 306'dır. Katılımcıların 167'si kadın (\%54,6), 139'u erkekti (\%48). Katılımcıların yaşları 65-90 arasındaydı ve yaş ortalaması $69,46 \pm 4,69$ 'du. Katılımcılardan 92 kişinin $(\% 30,1)$ birinci 
derece yakınlarında sağlık çalışanı vardı. Katılımcılardan 29 kişi COVID-19 hastalığını geçirmiş $(\% 9,5)$ olduğunu bildirdi. 75 kişi yakınlarından birinin COVID-19 hastalığını geçirmiş olduğunu $(\% 24,5)$ belirtmiştir. Haftada ortalama fiziksel aktivite 2,70 $\pm 2,51$ gün, günde yapılan fiziksel aktivite 1,04 $\pm 1,23$ saat olarak bulunmuştur. COVID-19 salgını sonrasında 247 kişi $(\% 80,7)$ fiziksel aktivitesinde azalma olduğunu bildirmiştir. Katılımcıların diğer sosyodemografik özelliklerine ait bilgiler Tablo 1 'de gösterilmiştir.

Kadın ve erkek cinsiyet sosyodemografik ve COVID-19 ile ilişkili özellikler açısından karşılaştırıldığında elde edilen sonuçlar Tablo 2 'de yer almaktadır. Kadınlarda yalnız yaşama $(p<0,001)$ ve bekar medeni durumun $(p<0,001)$ erkeklere göre anlamlı olarak daha sık olduğu ayrıca eğitim süresi $(p=0,001)$ ve gelir düzeyinin $(p=0,001)$ de anlamlı olarak daha düşük olduğu saptanmıştır.

Katılımcıların HADÖ depresyon alt ölçeği ortalama puanı $8,47 \pm 3,85$ olup, katılımcıların \%28,4'ü (s=87) eşik üstü puan almıştır. HADÖ anksiyete alt ölçeği ortalama puanı ise 8,06 $\pm 4,14$ olup katılımcıların \%28,8'i (s=88) eşik üstü puan almıştır.
HADÖ depresyon alt ölçek puan ortalamalarına göre eşik üstü puan alanlar ve almayanlar arasında birinci derece sağlık çalışanı yakını olması ve salgından sonra fiziksel aktivite azalması bakımından istatistiksel olarak anlamlı fark bulunmuştur. Birinci derece yakınlarında sağlık çalışanı olanlarda depresyon semptomu sıklığı daha az, günlük fiziksel aktivitesinde azalma olanlarda depresyon semptomu sıklığı daha fazla olarak tespit edilmiştir. HADÖ anksiyete alt ölçek puan ortalamalarına göre eşik üstü puan alanlar ve almayanlar arasında kadınların oranı erkeklere göre anlamlı olarak daha fazla bulunmuştur. Anksiyete alt ölçek puanı eşik üstü olanlarla olmayanlar arasında yaşadığı yer ve eğitim durumu açısından anlamlı farklılık saptanmıştır. Diğer parametrelerde depresyon veya anksiyete alt ölçek puanları eşik üstü olanlar ve olmayanlar arasında istatistiksel açıdan anlamlı fark bulunmamıştır (Tablo 3).

Fiziksel aktivite yapılan haftalık gün sayısı depresyon alt ölçek puanı eşik üstü olanlarda $2,18 \pm 2,34$, eşik üstü olmayanlarda 2,91 $\pm 2,55^{\prime}$ ti ve depresyon alt ölçek puanı eşik üstü olanlarla olmayanlar arasında anlamlı farklılık vardı $(p=0,022, \quad t=2,305)$. Fiziksel aktivite yapılan

Tablo 1. Katıımcıların sosyodemografik özellikleri

\begin{tabular}{|c|c|c|}
\hline & & n (\%) \\
\hline Yaşadığı yer & $\begin{array}{l}\text { Kırsal } \\
\text { Kentsel }\end{array}$ & $\begin{array}{l}97(31,7) \\
209(68,3)\end{array}$ \\
\hline Kiminle yaşıyor & $\begin{array}{l}\text { Yalnız } \\
\text { Ailesiyle }\end{array}$ & $\begin{array}{l}54(17,6) \\
252(82,4)\end{array}$ \\
\hline Medeni durumu & $\begin{array}{l}\text { Bekar } \\
\text { Evli }\end{array}$ & $\begin{array}{l}59(19,3) \\
247(80,7)\end{array}$ \\
\hline Eğitim durumu & $\begin{array}{l}\text { İlköğretim ve altı Lise mezunu } \\
\text { Üniversite mezunu }\end{array}$ & $\begin{array}{l}88(28,8) \\
43(14,1) \\
175(57,2)\end{array}$ \\
\hline Gelir durumu & $\begin{array}{l}0-3000 \text { lira } \\
3000-5000 \text { lira } \\
5000 \text { üstü }\end{array}$ & $\begin{array}{l}75(24,5) \\
90(29,4) \\
141(46,1)\end{array}$ \\
\hline Kronik hastalık & $\begin{array}{l}\text { Yok } \\
\text { Var }\end{array}$ & $\begin{array}{l}166(54,2) \\
140(45,8)\end{array}$ \\
\hline Psikiyatrik hastalık & $\begin{array}{l}\text { Yok } \\
\text { Var }\end{array}$ & $\begin{array}{l}278(90,8) \\
28(9,2)\end{array}$ \\
\hline Yakın akrabalarla görüşme sıklığında azalma & $\begin{array}{l}\text { Var } \\
\text { Yok }\end{array}$ & $\begin{array}{l}295(96,4) \\
11(3,6)\end{array}$ \\
\hline Yakın akrabalarla görüşme & $\begin{array}{l}\text { Ayda 1'den az } \\
\text { Ayda 1-2 kez } \\
\text { Ayda 3-4 kez } \\
\text { Ayda 4'ten fazla }\end{array}$ & $\begin{array}{l}189(61,8) \\
58(19,0) \\
31(10,1) \\
28(9,1)\end{array}$ \\
\hline
\end{tabular}


Tablo 2. Kadın ve erkek cinsiyetin diğer sosyodemografik özellikler, COVID-19 ile ilişkili özellikler, depresyon ve anksiyete düzeyleri açısından karşılaştırılması

\begin{tabular}{|c|c|c|c|c|c|}
\hline & & $\begin{array}{l}\text { Kadın } \\
\text { n (\%) }\end{array}$ & $\begin{array}{l}\text { Erkek } \\
\text { n (\%) }\end{array}$ & $x^{2}$ & $p$ \\
\hline Kiminle yaşıyor & $\begin{array}{l}\text { Yalnız } \\
\text { Ailesiyle }\end{array}$ & $\begin{array}{l}47(28,1) \\
120(71,9)\end{array}$ & $\begin{array}{l}7(5,0) \\
132(95,0)\end{array}$ & 27,872 & $<0,001$ \\
\hline Medeni durumu & $\begin{array}{l}\text { Bekar } \\
\text { Evli }\end{array}$ & $\begin{array}{l}53(31,7) \\
114(68,3)\end{array}$ & $\begin{array}{l}6(4,3) \\
133(95,7)\end{array}$ & 36,647 & $<0,001$ \\
\hline Eğitim durumu & $\begin{array}{l}\text { İlköğretim ve altı Lise } \\
\text { mezunu Üniversite } \\
\text { mezunu }\end{array}$ & $\begin{array}{l}88(37,1) \\
43(15,0) \\
175(47,9)\end{array}$ & $\begin{array}{l}26(18,7) \\
18(12,9) \\
95(68,3)\end{array}$ & 14,714 & 0,001 \\
\hline Gelir durumu & $\begin{array}{l}\text { 0-3000 lira } \\
3000-5000 \text { lira } \\
5000 \text { üstü }\end{array}$ & $\begin{array}{l}51(30,5) \\
55(32,9) \\
61(36,5)\end{array}$ & $\begin{array}{l}24(17,3) \\
35(25,2) \\
80(57,6)\end{array}$ & 14,282 & 0,001 \\
\hline Kronik hastalık & $\begin{array}{l}\text { Yok } \\
\text { Var }\end{array}$ & $\begin{array}{l}94(56,3) \\
73(43,7)\end{array}$ & $\begin{array}{l}72(51,8) \\
67(48,2)\end{array}$ & 0,616 & 0,433 \\
\hline COVID-19 geçirme öyküsü & $\begin{array}{l}\text { Yok } \\
\text { Var }\end{array}$ & $\begin{array}{l}149(89,2) \\
18(10,8)\end{array}$ & $\begin{array}{l}128(92,1) \\
11(7,9)\end{array}$ & 0,726 & 0,394 \\
\hline $\begin{array}{l}\text { Yakın akrabalarla görüşme sıklığında } \\
\text { azalma }\end{array}$ & $\begin{array}{l}\text { Yok } \\
\text { Var }\end{array}$ & $\begin{array}{l}7(4,2) \\
160(95,8)\end{array}$ & $\begin{array}{l}4(2,9) \\
135(97,1)\end{array}$ & 0,378 & 0,539 \\
\hline \multirow[t]{2}{*}{ Fiziksel aktivitede azalma } & $\begin{array}{l}\text { Yok } \\
\text { Var }\end{array}$ & $\begin{array}{l}36(21,6) \\
131(78,4)\end{array}$ & $\begin{array}{l}23(16,5) \\
116(83,5)\end{array}$ & 1,223 & 0,269 \\
\hline & & Kadın & Erkek & $\mathbf{t}$ & $p$ \\
\hline Yaş & ort $\pm S S$ & $69,62 \pm 5,14$ & $69,27 \pm 4,10$ & 0,661 & 0,509 \\
\hline HADÖ-depresyon & ort $\pm S S$ & $8,92 \pm 3,84$ & $8,80 \pm 4,17$ & 2,245 & 0,025 \\
\hline HADÖ- anksiyete & ort $\pm S S$ & $7,93 \pm 3,81$ & $7,17 \pm 3,94$ & 3,483 & 0,001 \\
\hline
\end{tabular}

HADÖ: Hastane Anksiyete Depresyon Ölçeği, SS: Standart Sapma

günlük saat depresyon alt ölçek puanı eşik üstü olanlarda $0,68 \pm 0,86$, eşik üstü olmayanlarda $1,19 \pm 1,33^{\prime}$ tü ve depresyon alt ölçek puanı eşik üstü olanlarla olmayanlar arasında anlamlı farklılık vardı $(p<0,001, \mathrm{t}=3,891)$.

Fiziksel aktivite yapılan haftalık gün sayısı anksiyete alt ölçek puanı eşik üstü olanlarda $2,35 \pm 2,38$, eşik üstü olmayanlarda $2,84 \pm 2,55^{\prime}$ ti ve anksiyete alt ölçek puanı eşik üstü olanlarla olmayanlar arasında anlamlı farklılık yoktu $(p=0,119, \mathrm{t}=1,277)$. Fiziksel aktivite yapılan günlük saat anksiyete alt ölçek puanı eşik üstü olanlarda $0,99 \pm 1,24$, eşik üstü olmayanlarda $1,07 \pm 1,23$ 'tü ve anksiyete alt ölçek puanı eşik üstü olanlarla olmayanlar arasında anlamlı farklılık yoktu $(p=0,621, \mathrm{t}=0,496)$.

Depresyon skoru ile haftalık fiziksel aktivite yapılan gün sayısı $(r=-0,136, p=0,018)$ ve günlük yapılan fiziksel aktivite saati ( $r=-$
$0,205, p<0,001)$ arasında istatistiksel olarak negatif yönde anlamlı fakat zayıf korelasyon bulunmuştur. Anksiyete skoru ile haftalık fiziksel aktivite yapılan gün sayısı ve günlük yapılan fiziksel aktivite saati arasında istatistiksel olarak anlamlı korelasyon bulunmamıştır $(p>0,05)$.

Lojistik regresyon analizinde HADÖ depresyon alt ölçek puanına göre eşik üstü depresyon semptomu varlığı bağımlı değişken, sağlık çalışanı yakını olmak, salgından sonra fiziksel aktivitede azalma olması bağımsız değişkenler olarak alınmıştır. Enter metod ile yapılan analiz sonucunda bağımsız değişkenlerin eşik üstü depresyon semptomu varlığının \%5'ini açıkladığı ve hem sağlık çalışanı yakını olmamasının hem de salgından sonra fiziksel aktivite azalmasının eşik üstü depresyon semptomu varlığını öngürücü olduğu saptanmıştır (Tablo 4). 
Tablo 3. Eşik üstü depresyon ve anksiyete semptomu olanlar ile olmayanların sosyodemografik ve COVID-19 ile ilişkili özellikler açısından karşılaştııııması

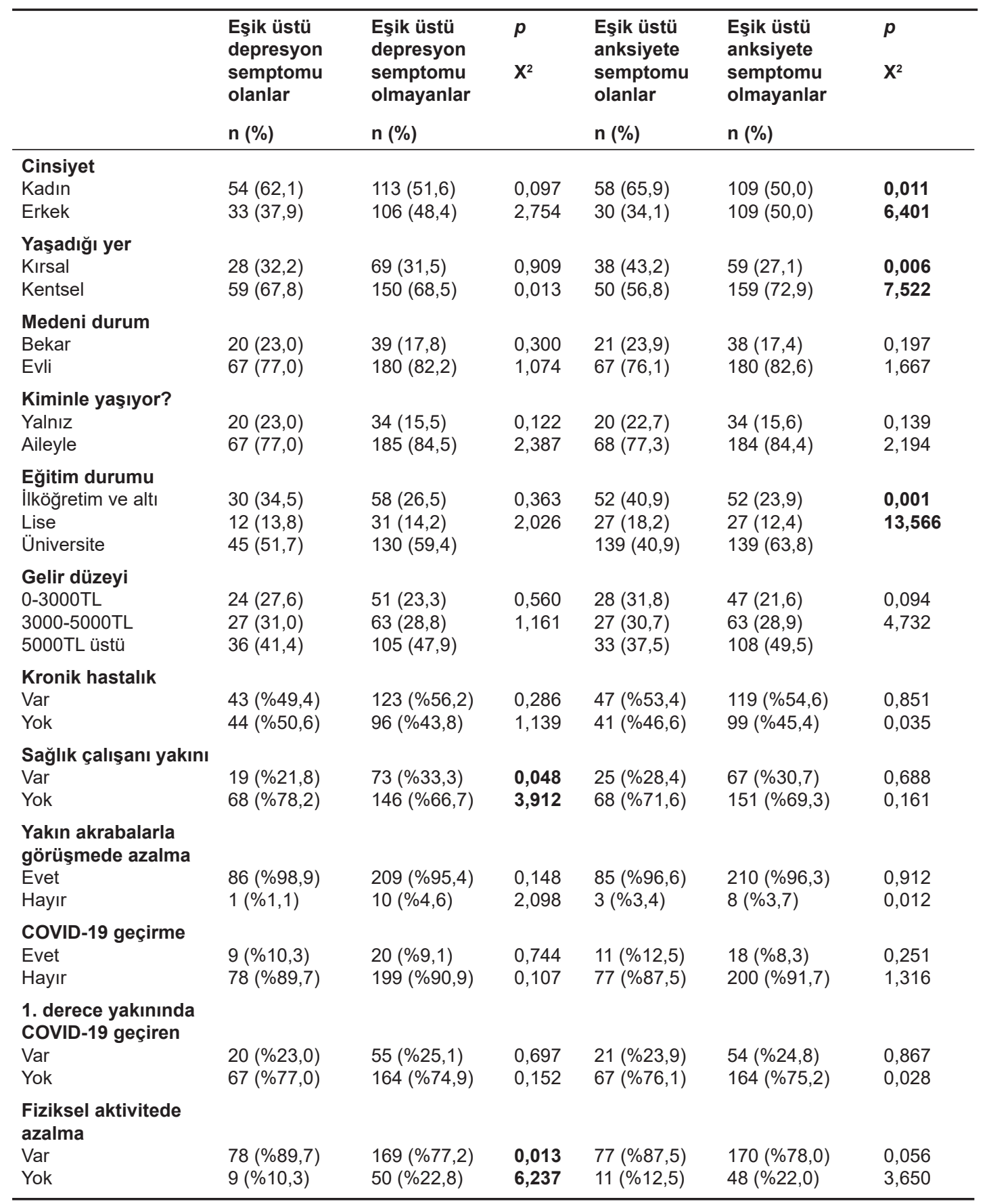

Tablo 4. Eşik üstü depresyon semptomu varlığını öngörücü faktörleri gösteren lojistik regresyon analizi

\begin{tabular}{lllllll}
\hline & B & Wald & $\boldsymbol{p}$ & Odds oranı & \%95 Güven aralığı \\
\hline Sağlık çalışanı yakını olması & $-0,603$ & 4,057 & 0,044 & 0,547 & $0,304-0,984$ \\
Fiziksel aktivitede azalma olması & 0,961 & 6,102 & 0,014 & 2,614 & $1,220-5,604$ \\
\hline
\end{tabular}


Lojistik regresyon analizinde HADÖ anksiyete alt ölçek puanına göre eşik üstü anksiyete semptom varlığı bağımlı değişken; cinsiyet, yaşadığı yer ve eğitim durumu bağımsız değişkenler olarak alınmıştır. Enter metod ile yapılan analiz sonucunda bağımsız değişkenlerin eşik üstü anksiyete semptomu varlığının \%9'unu açıkladığı kırsal alanda yaşamak ve daha kısa süre eğitim almış olmanın eşik üstü anksiyete semptomu varlığını öngörücü olduğu saptanmıştır (Tablo 5).

Tablo 5. Eşik üstü anksiyete semptomu varlığını öngörücü faktörleri gösteren lojistik regresyon analizi

\begin{tabular}{llllll}
\hline & B & Wald & $\boldsymbol{p}$ & Odds oranı & \%95 Güven aralığı \\
\hline Kadın cinsiyet & 0,530 & 3,740 & 0,053 & 0,589 & $0,344-1,007$ \\
Kırsal yerde yaşamak & 0,564 & 4,178 & 0,041 & 1,757 & $0,331-0,977$ \\
Eğitim durumu & & 7,197 & 0,027 & & \\
Eğitim durumu- ilköğretim ve altı & 0,755 & 6,367 & 0,012 & 2.128 & $1,184-3,825$ \\
Eğitim durumu- lise & 0,657 & 3,039 & 0,081 & 1,930 & $0,922-4,041$ \\
\hline
\end{tabular}

\section{Tartışma}

COVID-19 salgın sürecinin farklı demografik özelliklere sahip kişilerde çeşitli olumsuz psikolojik etkileri olmuştur. Hastalığın gidişatı ve bulaş riski bağlamında salgının olumsuz etkileri sağlık çalışanları ve ileri yaştaki kişilerde daha ön plana çıkmıştır. Bu çalışma da özellikli bir grup olmasına rağmen üzerine yapılan çalışmalar yetersiz olan ileri yaştaki kişileri hedef almıştır. İleri yaşta kişilerde COVID-19 salgını sürecinde eşik üstü depresyon ve anksiyete belirtilerinin sırasıyla $\% 28,8$ ve $\% 28,4$ gibi yüksek oranlarda ortaya çıktığı, depresif belirtiler ile günlük fiziksel aktivite azalmasının; anksiyete belirtileri ile kırsal alanda yaşamanın ve daha kısa süre eğitim almış olmanın ilişkili olduğu ayrıca sağlık çalışanı yakını olmanın depresif belirtiler için koruyucu bir faktör olduğu gösterilmiştir.

Bu çalışmada saptanan eşik üstü depresyon ve anksiyete belirtileri sıklığı COVID-19 salgını sürecinde yapılan diğer çalışmaların sonuçlarına [13] yakın olmakla birlikte salgın öncesinde yapılan toplum temelli çalışmaların oranlarına göre daha yüksektir [14-16]. Ülkemizde 104 ileri yaşta kişide yapılan çalışmada COVID-19 salgını sırasında depresif semptom sıklığı \%37,5, anksiyete semptom sıklığı \%29,8 [17]; 136 ileri yaşta kişiyle yapılan başka bir çalışmada ise bu oranlar sırasıyla \%16,9 ve $\% 25,7$ saptanmıştır [13]. Çalışmamızda eşik üstü depresyon ve anksiyete belirtilerinin sık ortaya çıktığının belirlenmesi bu belirtilerle ilişkili faktörlere yönelik önlemlerin alınması gerekliliğine dikkat çekmektedir.
Salgın sürecindeki karantinalarla birlikte depresyon ve anksiyete belirtilerinin ortaya çıkması ile ilgili en çok öne çıkan faktörlerden birisi sosyal izolasyon olmuştur. Sosyal kopukluk, depresyon ve anksiyete belirtilerinin ortaya çıkmasında önemli bir risk faktörüdür [18]. Çin'de yetişkinlerde yapılan bir çalışmada karantinadan etkilenenlerde etkilenmeyenlere göre anksiyete ve depresyon belirtilerinin daha sık ortaya çıktığı gösterilmiştir [19]. Sosyal toplantılara ve etkinliklere katılmak fiziksel aktiviteyi artıran bir uyarandır ayrıca diğer yaşlı yetişkinlerle etkileşim duyusal sistemleri, benlik saygısını, affektiviteyi, duygusal ve psikolojik destek algısını da uyarır [20, 21]. Bu çalışmada yüksek saptanan eşik üstü depresyon ve anksiyete belirtileri de ileri yaşta kişilerde uzayan sosyal mesafe ve karantina süreçleriyle ilişkili olabilir.

Garcia Portilla ve ark. [22] anksiyete ve depresyon sıklığının hem kadınlarda hem de erkeklerde 60 yaş altı olanlardan daha az olduğunu saptamıştır. Bu çalışma sadece ileri yaşlı kişileri değerlendirmiştir ve literatürde önceki çalışmalara bakıldığında depresyon ve anksiyete belirtilerinin daha sık olduğu gösterilmiş olsa da genç yaştaki kişilerle ileri yaştaki kişileri karşılaştırmamıştır. Ancak yaşlı yetişkinlerin, özellikle duygusal düzenleme ve problem çözme konusunda, genç olanlara göre psikolojik olarak daha dayanıklı olduğunu gösteren çalışmalar bulunmaktadır [23]. Salgın sürecinde birçok genç yetişkin birey işlerine gitmeyi ve internet aracılığıyla sosyal ilişkilerini sürdürmeyi kısmen de olsa devam 
ettirebilmişken ileri yaştaki kişiler çoğunlukla çalışmadıklarından ve internet kullanımları da genç yaştakiler kadar aktif olmadığından sosyal etkileşimleri daha kısıtlı kaldığından dayanıklılıklarını artıran faktörlerin etkileri azalmış olabilir. Bu koruyucu faktörlere rağmen ileri yaştaki kişilerin anksiyete ve depresyon risklerinin yüksek saptanması bu konuda önlem alma ve tedavi sağlama gerekliliğini vurgulamaktadır.

Genel popülasyonda olduğu gibi ileri yaşta kişilerde de sosyodemografik özellikler depresyon ve anksiyete belirtilerinin ortaya çıkmasını etkileyebilir. Ülkemizde yapılan başka bir çalışmada [13] olduğu gibi bu çalışmada da 65 yaş üstü kişilerde depresyon sıklığı kadın ve erkeklerde benzer, anksiyete sıklığı kadınlarda daha yüksek saptanmıştır. Ancak Garcia Portilla ve ark.'nın [22] yaptıkları çalışmada 60 yaş üstü olanlarda depresyon sıklığının kadınlarda \%28,5, erkeklerde \%14,2, anksiyete sıklığının kadınlarda \%2,7, erkeklerde $\% 1,3$ olduğunu ve kadınlarda depresyon riskinin daha yüksek olduğu gösterilmiştir. Bu çalışmada da hem depresyon hem anksiyete belirtisi düzeyleri kadınlarda erkeklerden daha yüksek saptanmıştır ancak eşik üstü semptom varlığının sıklığı değerlendirildiğinde depresyon belirtileri açısından bu farklılık tekrar gözlenmemiştir. Değerlendirme yöntemlerine ve örneklemlerin diğer demografik özelliklerine göre depresyon veya anksiyetenin cinsiyetlere göre sıklığı değişim gösteriyor olabilir ancak bu belirtilerin birlikte görülme durumunun oldukça sık olduğu göz önünde bulundurulduğunda her iki cinsiyette de bu belirtilerin varlığının ortaya çıkarılmasının önemi açıktır. Diğer demografik özelliklerle ilişkili olarak da ileri yaştaki kişileri hedefleyen bu çalışmada düşük eğitim ve gelir düzeyinin, kırsal alanda yaşamanın depresyon ve anksiyete semptomu sıklığını etkilediği görünmektedir. Hem yetişkinlerde hem de ileri yaşta kişilerde yapılan çalışmalar da bu bulguları desteklemektedir [17, 19]. Hipotezimizle de uyumlu olarak eğitim düzeyinin düşük olmasının eşik üstü anksiyete semptomları açısından bir risk faktörü olduğu saptanmıştır. Hastalık riskiyle karşı karşıya kalındığında eğitim düzeyi veya gelir düzeyi düşük olan, kırsal alanda yaşayan kişiler tehditle baş etme güçlerini daha düşük değerlendirebilirler. COVID-19 bazı yönleriyle belirsizliğin yüksek olduğu bir konuyken bilgiye erişimi kısıtlı olan kişilerde belirsizlik hissi çok daha fazla yaşanmış olabilir. Bu nedenlerle de günümüzde bilginin temel kaynağı olan internete erişimi ekonomik nedenlerle kısıtlı olan veya erişebilse de kullanma bilgisi kısıtlı olan eğitim düzeyi düşük kişiler anksiyete belirtilerine daha yatkın olabilirler.

İleri yaştaki kişilerde depresyon için risk faktörleri bulunmakla birlikte fiziksel aktivite gibi depresyondan koruyucu faktörler de bulunmaktadır [24]. Bu çalışmanın sonuçlarında $\% 80,7$ gibi yüksek bir oranda salgından sonra fiziksel aktivitesinde azalma olduğu bildirilmiştir ve hipotezimizle uyumlu olarak depresif belirtilerin fiziksel aktivitede azalma ile ilişkili olduğu saptanmıştır. Callow ve ark.'nın [25] 1046 ileri yaşta kişi ile yaptıkları çalışmada da bu çalışmanın sonuçlarıyla benzer şekilde daha çok fiziksel aktivite yapanların depresyon düzeylerinin daha düşük olduğu ancak fiziksel aktivite düzeyi ile anksiyete düzeyi arasında ilişki olmadığı saptanmıştır. Depresyon semptomu düzeyi ile haftalık fiziksel aktivite yapılan gün sayısı ve günlük yapılan fiziksel aktivite süresinin de ilişkili olduğu sonucu göz önünde bulundurulduğunda ileri yaştaki kişileri depresyondan korumak için fiziksel aktivitenin önemi ortaya çıkmaktadır. Daha önce yapılan çalışmalar da karantina süreçlerinin fiziksel aktivitede azalmaya yol açtığını ve bu durumun olumsuz psikolojik etkileri olduğunu vurgulamıştır [13, 26, 27]. Fiziksel aktivite ruhsal hastalık riskinde azalma ile ilişkili olduğundan [28] özellikle salgın süreçlerinde ileri yaşta kişilerin ruhsal sağlığını koruyabilmek için fiziksel aktiviteyi azaltacak durumların önüne geçilmeli hatta artırmayı sağlayacak koşullar sağlanmalıdır.

$\mathrm{Bu}$ çalışmayı diğer çalışmalardan farklı yapan özellikleri arasında COVID-19 geçiren kişileri de kapsaması, sağlık çalışanı yakını olup olmamasının da sorgulanması ve salgının psikolojik etkilerini bu açılardan da değerlendirebilmesi yer almaktadır. Elde edilen sonuçlar kendisi veya yakını COVID-19 geçirenlerle geçirmeyenlerin, kronik hastalığı olanlarla olmayanların depresyon ve anksiyete düzeylerinin benzer olduğunu ancak hipotezimizle uyumsuz olarak ileri yaşta kişilerin sağlık çalışanı yakını olmasının depresyon riski açısından koruyucu olabileceğini göstermektedir. Sağlık çalışanı yakını olan kişilerde bulaş riski daha çok bekleneceği için bu çalışmada sağlık çalışanı yakını olan kişilerde 
daha yüksek depresyon ve anksiyete semptom düzeyleri olacağı hipotez edilmiştir. Saptanan bu farklı sonuç sağlık çalışanlarının bulaşa yönelik önlemleri daha katı alması, yakınlarını daha iyi bilgilendirme olanakları olması ve sağlık hizmetlerine erişimi kolaylaştırabilmeleri nedenleriyle ilişkili olabilir. Daha önce yapılan çalışmalarda yakını COVID-19 geçiren kişilerde anksiyete düzeyinin daha yüksek olduğu gösterilmiştir [29]. Ancak yakını COVID-19 geçirmiş olmasına rağmen yaşamaya devam ediyorsa ileri yaştaki kişilerin bu durumu risk olarak algılaması azalmış olabilir ve bu nedenle de bu kişilerin depresyon ve anksiyete riski yüksek çıkmamış olabilir.

$\mathrm{Bu}$ çalışmanın kısıtıılıkları arasında kesitsel tasarımda olması, yüz yüze klinik görüşme yapılmamış olması, salgın öncesi dönemdeki durumlarına göre kişilerin psikolojik belirtilerindeki değişikliğin saptanamamış olması yer almaktadır. Bu çalışmanın sonuçları değerlendirilirken verilerin salgının başlangıcından 1 yıl sonra, salgının ülkemizdeki ikinci dalgasının olduğu ve aşılanmanın henüz başlanmadığı dönemde toplandığı göz önünde bulundurulmalıdır. Çalışmanın yapıldığı tarihlerde 65 yaş ve üstü olanlara hafta içi 3-4 saat sokağa çıkma izni mevcuttu ve hafta sonu sokağa çıkma yasakları uygulanıyordu. Sonuçların da bu koşullara göre yorumlanması uygun olacaktır. İleri yaşta kişiler üzerinde salgının etkilerinin daha net belirlenebilmesi için aşılanma gibi süreçteki değişiklikleri de değerlendirecek uzunlamasına çalışmalara intiyaç bulunmaktadır.

Salgın sürecinde ileri yaştaki kişilerin fiziksel sağlığının yanı sıra ruhsal sağlığının korunması da önemlidir. COVID-19 salgınında da ileri yaşta kişilerde depresyon ve anksiyete belirtileri sıklıkla ortaya çıkmaktadır. İleri yaşta kişilerden özellikle kırsal alanda yaşayan, eğitim düzeyi düşük olanların psikolojik durumları daha sık takip edilmelidir ve ileri yaşta kişilerin fiziksel aktivitelerini sürdürmelerini sağlayacak önlemler alınmalıdır.

Çıkar ilişkisi: Yazarlar çıkar ilişkisi olmadığını beyan eder.

\section{Kaynaklar}

1. Applegate WB, Ouslander JG. COVID-19 Presents high risk to older persons. J Am Geriatr Soc 2020;68:681. https://doi.org/10.1111/jgs.16426
2. Bialek S, Boundy E, Bowen V, et al. Severe outcomes among patients with Coronavirus Disease 2019 (COVID-19) - United States, MMWR Morb Mortal Wkly Rep 2020;69:343-346. https://doi.org/10.15585/mmwr. $\mathrm{mm} 6912 \mathrm{e} 2$

3. Hua W, Xiaofeng L, Zhenqiang B, Jun R, Ban W, Liming $\mathrm{L}$. The epidemiological characteristics of an outbreak of 2019 novel coronavirus diseases (COVID-19) in China. Chin J Epidemiol 2020;41:145-151. https://doi. org/10.3760/cma.j.issn.0254-6450.2020.02.003

4. Loyola WS, Camillo CA, Torres CV, Probst VS. Effects of an exercise model based on functional circuits in an older population with different levels of social participation. GeriatrGerontol Int GeriatrGerontol Int 2018;18:216-223. https://doi.org/10.1111/ggi.13167

5. Sepúlveda Loyola W, Ganz F, Maciel RPT, et al. Social participation is associated with better functionality, health status and educational level in elderly women. Brazilian J Dev 2020;6:20690-20701. https://doi. org/10.34117/bjdv6n4-299

6. Santini $\mathrm{ZI}$, Nielsen L, Hinrichsen C, et al. Social disconnectedness, perceived isolation, and symptoms of depression and anxiety among older Americans (NSHAP): a longitudinal mediation analysis. Lancet Public Heal 2020;5:62-70. https://doi.org/10.1016/ S2468-2667(19)30230-0

7. Adamson JA, Price GM, Breeze E, Bulpitt CJ, Fletcher AE. Are older people dying of depression? Findings from the medical research council trial of the assessment and management of older people in the community. J Am Geriatr Soc 2005;53:1128-1132. https://doi.org/10.1111/j.1532-5415.2005.53355.x

8. Canuto A, Weber K, Baertschi M, et al. Anxiety disorders in old age: psychiatric comorbidities, quality of life, and prevalence according to age, gender, and country. Am J Geriatr Psychiatry 2018;26:174-185. https://doi.org/10.1016/j.jagp.2017.08.015

9. Lebowitz BD, Pearson JL, Schneider LS, et al. Diagnosis and treatment of depression in late life: consensus statement update. JAMA 1997;278:11861190.

10. Kirmizioglu $Y$, Doğan $O$, Kuğu N, Akyüz G. Prevalence of anxiety disorders among elderly people. Int J Geriatr Psychiatry 2009;24:1026-1033. https://doi. org/10.1002/gps.2215

11. Zigmond AS, Snaith RP. The hospital anxiety and depression scale. Acta PsychiatrScand 1983;67:361370. https://doi.org/10.1186/1477-7525-1-29

12. Aydemir O, Guvenir T, Kuey L, Kultur S. Validity and reliability of Turkish version of hospital anxiety and depression scale. Turk PsikDerg 1997;8:280-287.

13. Yurumez Korkmaz B, Gemci E, Cosarderelioglu C, et al. Attitudes of a geriatric population towards risks about COVID-19 pandemic: in the context of anxiety and depression. Psychogeriatrics 2021;21:730-737. https://doi.org/10.1111/psyg.12731 
14. Byers AL, Yaffe K, Covinsky KE, Friedman MB, Bruce ML. High occurrence of mood and anxiety disorders among older adults: The National Comorbidity Survey Replication. Arch Gen Psychiatry 2010;67:489-496. https://doi.org/10.1001/archgenpsychiatry.2010.35

15. Andreas S, Schulz H, Volkert J, et al. Prevalence of mental disorders in elderly people: the European MentDis_ICF65+ study. Br J Psychiatry 2017;210:125131. https://doi.org/10.1192/bjp.bp.115.180463

16. Yaka E, Keskinoglu P, Ucku R, Yener GG, Tunca Z. Prevalence and risk factors of depression among community dwelling elderly. Arch GerontolGeriatr2014;59:150-154. https://doi. org/10.1016/j.archger.2014.03.014

17. Cigiloglu A, Ozturk ZA, Efendioglu EM. How have older adults reacted to coronavirus disease 2019? Psychogeriatrics 2021;21:112-117. https://doi. org/10.1111/psyg.12639

18. Santini $\mathrm{ZI}$, Jose PE, York Cornwell E, et al. Social disconnectedness, perceived isolation, and symptoms of depression and anxiety among older Americans (NSHAP): a longitudinal mediation analysis. Lancet Public Health 2020;5:62-70. https://doi.org/10.1016/ S2468-2667(19)30230-0

19. Lei L, Huang X, Zhang S, Yang J, Yang L, Xu M. Comparison of prevalence and associated factors of anxiety and depression among people affected by versus people unaffected by quarantine during the COVID-19 epidemic in Southwestern China. Med Sci Monit 2020;26:1-12. https://doi.org/10.12659/ MSM.924609

20. Douglas H, Georgiou A, Westbrook J. Social participation as an indicator of successful aging: an overview of concepts and their associations with health. Aust Health Rev 2017;41:455-462. https://doi. org/10.1071/AH16038

21. Tomioka K, Kurumatani N, Hosoi H. Social participation and the prevention of decline in effectance among community-dwelling elderly: a population-based cohort study. PLoS One 2015;10:e0139065. https://doi. org/10.1371/journal.pone.0139065

22. García Portilla P, de la Fuente Tomás L, Bobes Bascarán $\mathrm{T}$, et al. Are older adults also at higher psychological risk from COVID-19? Aging MentHeal Routledge 2021;25:1297-1304. https://doi.org/10.1080 /13607863.2020.1805723

23. Gooding PA, Hurst A, Johnson J, Tarrier N. Psychological resilience in young and older adults. Int J GeriatrPsychiatry 2012;27:262-270. https://doi. org/10.1002/gps. 2712

24. Strawbridge WJ, Deleger S, Roberts RE, Kaplan GA. Physical activity reduces the risk of subsequent depression for older adults. Am $\mathrm{J}$ Epidemiol 2002;156:328-334. https://doi.org/10.1093/aje/kwf047
25. Callow DD, Arnold Nedimala NA, Jordan LS, et al. The mental health benefits of physical activity in older adults survive the COVID-19 pandemic. Am J Geriatr Psychiatry 2020;28:1046-1057. https://doi. org/10.1016/j.jagp.2020.06.024

26. Rogers NT, Waterlow NR, Brindle H, et al. Behavioral change towards reduced intensity physical activity is disproportionately prevalent among adults with serious health issues or self-perception of high risk during the UK COVID-19 lockdown. Front Public Health 2020;8:575091. https://doi.org/10.3389/ fpubh.2020.575091

27. Lesser IA, Nienhuis CP. The impact of COVID-19 on physical activity behavior and well-being of canadians. Int J Environ Res Public Health 2020;17:3899. https:// doi.org/10.3390/ijerph17113899

28. Teychenne M, White RL, Richards J, Schuch FB, Rosenbaum S, Bennie JA. Do we need physical activity guidelines for mental health : what does the evidence tell us? Ment Health Phys Act 2020;18:100315. https:// doi.org/10.1016/j.mhpa.2019.100315

29. Mazza C, Ricci E, Biondi S, et al. A nationwide survey of psychological distress among italian people during the covid-19 pandemic: Immediate psychological responses and associated factors. Int J Environ Res Public Health 2020;17:1-14. https://doi.org/10.3390/ ijerph17093165

Etik kurul onayı: Pamukkale Üniversitesi Girişimsel Olmayan Klinik Araştırmalar Etik Kurulu'ndan 02.02.2021 tarih ve 03 sayılı izin alınmıştır.

\section{Yazarların makaleye olan katkıları}

B.Y. ve A.B. çalışmanın ana fikrini ve hipotezini kurgulamışlardır. B.Y. ve A.B. teoriyi geliştirmiş, gereç ve yöntem bölümünü düzenlemişlerdir. Sonuçlar bölümündeki verilerin değerlendirmesini B.Y. ve A.B. yapmışlardır. Ayrıca tüm yazarlar çalışmanın tamamını tartışmış ve son halini onaylamıştır. 